\title{
Improving reading comprehension: From metacognitive intervention on strategies to the intervention on working memory executive processes*
}

\author{
Mejorando la comprensión lectora: Desde la intervención \\ metacognitiva en estrategias a la intervención en los \\ procesos ejecutivos de la memoria operativa
}

Recibido: junio 1 de 2012 | Revisado: agosto 1 de 2012 | Aceptado: octubre 10 de 2012

\author{
ElosúA, M.R.** \\ GARCÍA-MADRUGA, J.A. \\ VILA, J.O. \\ GÓMEZ-VEIGA, I. \\ Universidad Nacional de Educación a Distancia, Spain \\ GIL, L. *** \\ Valencia University, Spain
}

Doi: 10.11144/Javeriana.UPSY12-5.ircm

Para citar este artículo: Elosúa, M.R., GarcíaMadruga, J.A., Vila, J.O., Gómez-Veiga, I., \& Gil, L. (2013). Improving reading comprehension: From metacognitive intervention on strategies to the intervention on working memory executive processes. Universitas Psychologica, 12(5), 1425-1438. Doi: 10.11144/Javeriana.UPSY12-5.ircm

* This research was conducted while M. Rosa Elosúa and Juan Antonio García Madruga were receiving Grant DGICYT PSI2008-00754 and ConsoliderIngenio 2010 (CSD2008-00048), both from the Ministry of Science and Innovation of Spain.We thank students who voluntarily participated in this research

** Universidad Nacional de Educación a Distancia, Spain. Area of research: Working memory; Text Comprehension; Executive Processes; Strategies on Cognitive Training. Correspondence and requests for reprints should be addressed to: M. Rosa Elosúa. Departamento Psicología Básica I. Facultad de Psicología. UNED. C/ Juan del Rosal, 10. 28040 Madrid (SPAIN) Tfno.: +3491 3986224 Fax: +34 913987972 e-mail:melosua@psi.uned.es

**** Valencia University, Spain.

\section{A B S T R A C T}

Many students may read fluently but have difficulties constructing meaning from texts. Difficulties with reading comprehension have many implications at school. In particular, problems understanding texts interfere with studying and learning from text. Reading comprehension has improved in the last 30 years focusing on intervention programs that work with strategies in which metacognition plays a crucial role. However, recent years have seen relevant advances in the study of the relationship between working memory (WM), particularly executive processes, and reading comprehension. In this paper, we present how the last 20 years of our research has evolved regarding metacognitive intervention from text comprehension strategies, as the main idea and summarization to the intervention on WM's executive processes during reading. Thus, our more recent empirical data has shown that text comprehension can be improved after specific training on the executive functions of working memory (e.g., focusing, switching, connecting and updating mental representations, and the inhibition of irrelevant information) in Primary school students.

Key words authors

Reading comprehension, text comprehension strategies, metacognition, training working memory, executive functions.

Key words plus

Neuropsychology, Cognitive Science, Development.

\section{RES U MEN}

Muchos estudiantes pueden leer de forma fluida pero presentan dificultades para construir significados a partir de los textos. Las dificultades de compresión lectora tienen varias implicaciones en la escuela. En particular, los problemas de comprensión de textos interfieren con el estudio y el aprendizaje desde el texto. La comprensión de lectura se ha mejorado en los últimos 30 años enfocándose en los programas de intervención que trabajan con estrategias en las cuales la metacognición juega un papel crucial. Sin embargo, en años recientes han sido relevantes los avances en el estudio de las relaciones entre la memoria de trabajo (WM), particularmente el proceso ejecutivo, y la comprensión de lectura. En este artículo presentamos la manera como se ha desarrollado nuestra investigación en los últimos 20 
años, en relación con intervención metacognitiva desde las estrategias de comprensión de textos, tales como la idea principal y el resumen en la intervención sobre el proceso ejecutivo de WM durante la lectura. Así, nuestros datos empíricos recientes han mostrado que la comprensión de textos puede ser mejorada después del tratamiento específico sobre las funciones ejecutivas de memoria de trabajo (e.g., enfocándose, cambiando, conectando y actualizando las representaciones mentales y la inhibición de información irrelevante) en niños de escuela primaria.

Palabras clave

Comprensión de lectura, estrategias de comprensión de texto, metacognición, entrenamiento en memoria de trabajo, funciones ejecutivas.

Palabras clave descriptores

Neuropsicología, Ciencia Cognitiva, desarrollo.

\section{Introduction}

Difficulties with reading comprehension have many implications in school. Specifically, problems understanding texts interfere with studying and learning from text. In fact, most teachers usually complain about the difficulties their pupils have in paying attention to what they are reading during daily classroom activities. These kinds of problems with text comprehension have a great impact on academic achievement.

In this paper we focus on higher-order comprehension problems that are not caused by decoding skill deficits or difficulties with lexical access (see Cain \& Oakhill, 2007; Rapp, Van den Broek, McMaster, Kendeou, \& Espin, 2007). Students with these types of problems may read fluently but have difficulties constructing meaning. How have these comprehension problems been dealt with in cognitive science? Many papers and handbooks have focused on reading comprehension and comprehension instruction (see Baker \& Beal, 2009; Block \& Pressley, 2002; Block, Gambrell, \& Pressley, 2002; Kamil, Pearson, Moje, \& Afflerbach, 2011; Klingner, Morrison \& Eppolito, 2011; McNamara, 2007; Oakhill \& Kane, 2007a, 2007b).

The scope of this field of knowledge is too large to attempt to be covered here. The aim of this paper is much more limited. In this study, we present how the last 20 years of our research has evolved regarding metacognitive intervention from text comprehension strategies, as the main idea and summarization, to the intervention on WM's executive processes during reading. Thus, our more recent empirical data show that text comprehension can be improved after specific training on the executive functions involved in working memory (e.g., focusing, switching, connecting and updating mental representations, and the inhibition of irrelevant information) in Primary school children.

First, we describe an overall summary regarding some of the strategies most often used in reading intervention programs, using our empirical data as an example of this kind of study. Second, we describe from our most recent studies some of the main executive processes of working memory that have been studied to improve reading comprehension. Finally, we draw some conclusions from these studies to illustrate the nature of the changes that have occurred over the past 30 years.

\section{Reading intervention programs focusing on specific strategies}

What kind of specific cognitive strategies have been used in text comprehension programs? This paper presents a brief summary of some specific strategies that help students to be aware of and regulate their thinking processes that surrounds comprehension. Two types of strategies are reviewed: teaching the main idea and summarization. In this way, we are focusing on some of the most frequent strategies used in this field (see Block \& Pressley, 2002; Cain \& Oakhill, 2007; Kamil et al., 2011). Furthermore, these two strategies were implemented as well in every one of our studies (Elosúa, García-Madruga, Gutiérrez, Luque, \& Gárate, 2002; García-Madruga, Martín Cordero, Luque, \& Santamaría, 1992, 1995).

To teach readers to identify the "main idea" in texts is a well-known approach that has had a positive impact on text comprehension. Some studies (e.g. Elosúa et al., 2002; Stevens, 1988; Van den Broek, Lynch, Naslund, Ievers-Landis, \& Verduin, 2003; Williams, 1988) support instructional approaches that focus on the identification and con- 
struction of the main ideas, as cognitive strategies that are essential for studying and learning from texts. The identification of the main idea of a text is an important step to be able to summarize that text. Williams (1988) has shown how important is to get the main idea, as a basic aspect of reading comprehension, in order to draw inferences, to study and to learn from text. And this difficulty is always present, in both children and university students.

It is also important to consider that reading comprehension requires knowledge of text structures. The nature of the main idea depends on text structure, as Bauman (1986), Meyer $(1975,1984)$ and Williams (2004) have extensively argued. In narrative texts, the reader has to identify the main idea through the description of events (for example, a protagonist effecting actions that produce results in different ways...) that occurs in a temporal sequence. In expository text, readers have to discover the structure of the text (e.g., description of facts, compare-contrast, cause-effect, problem-solution...). Some studies (Meyer, 1975, 1984; Williams, 2004; Williams \& Pao, 2011) have highlighted diverse features of narrative and expository text structures that enable the reader to organize text content, and to construct a mental representation necessary for comprehension.

Explicit main ideas are easier than implicit main ideas (Baumann, 1984). When texts explicitly show the main ideas, readers only have to select it from the text. However, if the main idea is implicit, readers have to generalize or even construct a statement to represent the main idea of the text. These cognitive macrorules (selection, generalization and construction) can be taught. The main idea selection is easier than the generalization and construction of the main idea (Elosúa et al., 2002). In other words, the macrorules of selection, generalization, and construction are necessary in developing the strategy of identifying the main idea. Furthermone, text structure may support a readers' identification of main ideas, as Bonnie Meyer (1975, 1984) has found.

The difficulty in understanding the main idea is also affected by its position in text. Sometimes the main idea is placed at the beginning, but it could also be at the end or in the middle of the text. So, the instruction about the position of the main idea of the text is important. Identification of the main idea at the beginning of the text is generally easier than when positioned elsewhere (Baumann, 1986; Elosúa et al., 2002).

Baumann (1984) completed a well-known study in the instruction of comprehending the main idea by using the principles of direct instruction to teach sixth-grade students in a direct way to identify the main ideas in stories that were explicit or implicitly stated.

Some studies (Bauman, 1984; Jitendra \& Gajria, 2011) have shown that the task of training participants in the selection, generalization and/ or construction of the identification of the main idea requires them not only to pay attention to the explicit or implicit ideas, or their position, but also to link the more meaningful ideas, ordering and identifying the main idea as a result. In our studies (Elosúa et al., 2002; García-Madruga et al., 1992, 1995) the intervention program based on identifying main ideas was useful in different age groups (12 and 16 year olds in Elosúa et al., 2002; 17 and 18 year olds in García-Madruga, Martín Cordero, Luque, \& Santamaría, 1995). It involves using many and different kinds of text structures of various lengths. It could be interesting to apply this strategy to different disciplines or areas of study such as science, History, Social Sciences and so on (see also Jitendra \& Gajria, 2011). In these studies the authors describe their work on instructional programs including the explicit instruction in strategies with extensive practice opportunities, as well as the ongoing assessment of the students' use of these strategies. Jitendra and Gajria (2011) provide extended teaching scripts and simple passages that clearly illustrate how teachers can implement this instruction. It is also possible to make adaptions to the relevant main idea identification strategy because trainers can use longer and more complex texts.

The strategy of "summarization" is the ability to construct a concise account of the main ideas in a text. In fact, we deal with two different cognitive 
strategies (e.g. main idea and summarization). The summarization strategy, however, first requires to identify the main ideas in the text. In other words, the first strategy should be seen as a prerequisite of the second.

A good summary is an accurate indication about how well the text has been understood. Summarization training enhances not only the main ideas of the text, but also the different interrelationships among those key ideas. As Gitendra and Gajria (2011, p. 202) describes, "the goal of summarization training is to make children aware of the highest level of information or main ideas in a text, as well as details that support the main ideas, because both are important to remember for school success".

The summarization strategy involves the same underlying processes presupposed by the model of text comprehension of Kintsch and Van Dijk (1978). It is well known that in this model the global meaning of the text (what is called the "macrostructure") is critical. Within the framework of the theory proposed by Kintsch (Kintsch \& Van Dijk, 1978; Van Dijk \& Kintsch, 1983; Kintsch, 1988, 1998), a distinction between the text microstructure and macrostructure is established. The former is the local structure of the text, that is, the semantic content of sentences in text. The macrostructure of a text consists of a hierarchy of propositions representing its global structure, derived from the microstructure. Thus, the macrostructure that one constructs during reading is like a summary: It represents the core of the text (and the macropropositions summarize the general idea of the text).

According to this comprehension model, the construction of these macropropositions is carried out by applying certain macrorules that allow the information contained in the text to be reduced and organized. As we have already mentioned above, these macrorules are selection, generalization, and construction. Whereas the selection macrorule basically requires a process of recognition, the generalization macrorule is more complex because it is based on a logical relation of inclusion. A construction is even more complex, as it requires relationships of various types to be determined from among the elements and ideas of the text. Some studies (Brown \& Day, 1983; Caccamise, Franzke, Echkoff, Kintsch, \& Kintsch, 2007; Elosúa et al., 2002; Rinehart, Stahl, \& Erikson, 1986; Winograd, 1984) have shown that students develop the summarization strategy following the training on these basic macrorules of Kintsch and Van Dijk's (1978) model using different kinds of texts, with more or less complexity and of various lengths. Therefore, the macrorules of selection, generalization, and construction are also necessary to develop the summarization strategy.

Once again, knowledge about text structure is important in the acquisition of the strategy of summarization. Good readers are more aware of the structure of a text in order to properly summarize it (Cain, Oakhill, Barnes, \& Bryant, 2001). It can be said that the proper text structure helps students to put specific macrorules into action in order to construct the gist of the text. As a consequence, intervention programs focusing on summary formation may be beneficial for poor readers. Research in strategy training involving the summarization of texts is known both to enhance written summaries and result in transfer effects on a variety of reading comprehension measures (Caccamise et al., 2007; Elosúa et al., 2002; Rinehart et al., 1986; Winograd, 1984).

In general, these studies have shown empirical support for the systematic instruction of strategies such as the main idea and summarization strategy in order to increase the reading comprehension of readers. As Baker and Beal (2009, p. 373) have expressed, more than 30 years have passed since research on metacognition began with the work of John Flavell (1976) and Ann Brown (1978). Nowadays, the majority of intervention programs have a metacognitive approach, in the sense that participants not only learn the different strategies, but are also taught to be aware of when and how to apply them adequately, regardless of the contents. This should include the key dimension of self-evaluation as well as monitoring the results of the task.

Three basic components -direct instruction, modeling, and practice- have been integrated into this metacognitive approach. Intervention program 
procedures could be organized by taking the three recurrent phases into account, relative to each component: 1) direct instruction consisting of a specific description of the strategy to be used and how and when to use it, with concrete examples; 2) explicit and detailed modeling by the teacher or trainer when applying the strategy being trained; and 3) practice using practical exercises in which the pupils are given the opportunity to use the strategy, first under the guidance of an instructor, and then, 4) as an independent practice, that is, giving the participants different opportunities to practice on their own (see Kamil et al., 2011).

The metacognitive training of text comprehension strategies enhances the importance of active processing during reading. As some authors have highlighted (García-Madruga et al., 1992; Kintsch, 1988, 1998), in order to achieve an integrated representation of texts, it is not sufficient to have the appropriate knowledge; readers really need to activate and apply this knowledge during the reading process.

In reading intervention research, it is important to clarify that specific cognitive strategies (e.g. main idea identification and summarization) are different from metacognitive strategies. In fact, a specific set of strategies is particularly relevant to comprehension; these are called metacognitive strategies. Metacognitive strategies are routines and procedures that allow individuals to monitor and assess their ongoing performance in accomplishing a cognitive task. Students who use metacognitve strategies are aware of the cognitive resources they have to test, revise and evaluate their comprehension process. Baker and Brown (1984) have described the kinds of metacognitive strategies or comprehension monitoring that good readers execute as they read. For example, they ask themselves: "Is there something I don't understand? Are there any gaps in my knowledge to understand this text? Am I learning this material? Can I repair the gap so that my understanding is complete?" These compensatory strategies restore understanding and learning. It is important to clarify that metacognitive strategies such as the monitoring and evaluation of comprehension are not the specific purpose of this paper.
However, in our first intervention programs (Elosúa et al., 2002; García-Madruga et al., 1992, 1995) we tried to teach not only the cognitive strategies of "main idea" and "summarization", but also to carry out a metacognitive and active intervention, trying to develop an active practice in the use of those strategies. These cognitive strategies are different from the metacognitive strategies of monitoring the comprehension process that we previously mentioned, although the metacognitive perspective is included in our metacognitive and active intervention.

How should these intervention programs focused on main idea and summarization strategies be implemented in schools? To what degree were teachers involved? And do positive results from lab studies meet the complex situation of daily classroom teaching? It seems that the three basic components of direct instruction, modeling, and practice could be integrated in the way teachers appropriate this metacognitive approach. Furthermore, some studies (e.g. Jitendra \& Gajria, 2011) have shown how teachers might implement the instructions regarding the adaptation of the strategy of main idea to different settings in schools, as we have already mentioned. However, it is important to highlight that we need to learn more about comprehension strategies across the full range of age and grade levels (Elosúa et al., 2012; López Escribano, Elosúa, Gómez-Veiga, \& García Madruga, 2013) and across a range of variation, such as reader differences, text types, and instructional contexts (see Sweet, 2003).

The metacognitive and active text processing approaches, hence stress the role of executive control processes in reading comprehension. In the next section we will describe reading intervention programs that focus on working memory's executive processes.

\section{Reading intervention programs focusing on working memory's executive processes.}

In the past 30 years, many researchers in the field of reading and text comprehension have investigated the role of working memory (WM), a memory system assumed to be involved in the active processing of current information (Baddeley \& Hitch, 1974). 
Many studies have demonstrated the importance of working memory in decoding and comprehension (Cain, Oakhill, \& Lemmon, 2004; Carretti, Borella, Cornoldi, \& De Beni, 2009; Savage, Lavers, \& Pillay, 2007). In fact, reading comprehension requires the integration of meaning across words, sentences and passages in the text. Therefore, there are demands on working memory at various levels: (a) the individual word level (recall and retention of semantic meaning), (b) the sentence-level (merging of the syntactic and semantic cues to create a proposition), and (c) the text-level (synthesizing propositions into a coherent idea).

Research has shown a strong and consistent relationship between measures of working memory and comprehension (Daneman \& Carpenter, 1980; Daneman \& Merikle, 1996; Cain et al., 2004). Skilled readers appear to manage integrated and cohesive text comprehension with little effort. However, less-skilled readers show specific and consistent impairments in the components required building these cohesive representations, leading to the hypothesis that impairment in working memory may underlie problems in text comprehension. Students with high WM scores show good comprehension reading skills, and conversely, students with poor WM scores tend to perform below average on reading comprehension measures (Cain et al., 2004; Carretti et al., 2009; Savage et al., 2007).

Before moving on to WM's executive functions, it seems convenient to stress the influence of other variables in the comprehension process. As Oakhill and Cain (2007a, 2007b) have reviewed, vocabulary is an important predictor of comprehension skills, and there is some evidence that the relation between vocabulary and comprehension development may be reciprocal, at least in Primary students.

\section{Working Memory Executive functions}

The model of working memory developed by Baddeley (Baddeley \& Hitch, 1974) is one of the most used in the field of text comprehension (see also Kintsch, 1998). In this model, there are four components: a central executive with a limited capacity, which controls and coordinates the other three components: the phonological loop, the visuo-spatial sketchpad and the episodic buffer.

The main component of the working memory system is the central executive. It not only has to co-ordinate the other components, but it is also in charge of the attentional control of information. That is, it has to focus and switch attention, to activate representations, to inhibit automatic processes and to discard irrelevant information. The development and capacity of central executive functions (Gathercole, Lamont, \& Alloway, 2006; St Clair-Thompson \& Gathercole, 2006) has been shown to support reading comprehension and academic skills.

We consider that text comprehension is a highly demanding cognitive task that implies the simultaneous process of extracting and constructing meaning (Sweet \& Snow, 2003). As numerous authors have maintained, working memory plays a crucial role in storing the intermediate and final products of readers' computations, as well as coordinating the processes of constructing and integrating the semantic representation from a text (e.g. Cain, 2006; Ericsson \& Kintsch, 1995; Gathercole \& Baddeley, 1993; Just \& Carpenter, 1992). The necessary metacognitive monitoring during reading underscores the importance of attentional control and enhances the role of executive functioning in reading comprehension (e.g. Baker \& Beal, 2009).

The relationship between working memory span and reading comprehension has been well established in the literature (see Daneman \& Merikle, 1996; Savage et al., 2007). Recently, an increasing number of authors have highlighted the role of the diverse interrelated executive processes of WM in reading comprehension. In particular, (Carretti, Cornoldi, De Beni, \& Romanó, 2005) have linked WM's updating to reading comprehension skills; likewise, (Carretti, Borella, Cornoldi, \& De Beni, 2009) and (Savage, Cornish, Manly \& Hollis, 2006) have underscored the function of inhibiting and discarding information in reading comprehension.

Some studies have recently shown (Cain, 2006; Gaskins \& Pressley, 2007; Gathercole et al., 2006; Holmes, Gathercole, \& Dunning, 2009; Klingberg, 2010; Meltzer, Pollica, \& Barzillai, 2007) that 
these working memory executive processes can be improved and trained in an explicit way in educational settings. In this paper we try only to illustrate how this kind of training on executive functions of working memory might be implemented.

A recent meta-analytic review (Melby-Lervåg \& Hulme, 2012) has questioned the efficacy of training studies on WM. According to these authors, training programs yield only near-transfer effects and there is not any evidence that these effects are durable. Likewise, Melby-Lervåg and Hulme (2012) cast doubt on the relevance and theoretical basis of studies that argue WM training can enhance cognitive functioning. However, as these authors explicitly acknowledge, the problem with meta-anlyses is that they bring together studies that widely differ in their characteristics and theoretical perspectives. We agree with Melby-Lervåg and Hulme (2012) that some of the training programs need a clearer analysis of the processes involved and the training tasks used. In our work (García-Madruga et al., 2013), we have attempted to be more precise in the analysis of the executive processes trained in every task used in the training program.

Our research (García-Madruga et al., 2013) has attempted to evaluate a training program on the executive functions of working memory (e.g., focusing, switching, connecting and updating mental representations, and the inhibition of irrelevant information) in Primary school children (8 and 9 years old children). We hypothesized that specific training on the executive functions of working memory will improve reading comprehension.

The battery of tasks included in the training enabled us to systematically vary demands on the executive abilities required to perform them successfully in different proportions. The focusing function is present in all the tasks since they require children to focus their attention on specific and relevant information for solving the task. The switching' function is particularly present in some tasks in which readers have to shift back and forth between diverse pieces of information included into the task. Connecting with long-term knowledge is particularly necessary when performing tasks that require combining information from the task with information from long-term memory. The function of updating mental representations function is particularly necessary in those tasks which require monitoring and coding incoming information for relevance to the task at hand and then appropriately revising the items held in working memory by replacing old, no longer relevant information with newer, more relevant information.

TABLE 1

The executive processes trained, their icons, and the tasks used.

\begin{tabular}{|c|c|c|}
\hline Executive Function & Icons & Tasks tapping each executive function \\
\hline Focusing & & $\begin{array}{l}\text { Vignettes in Order, Decoding Instructions, Sentences in Order, Anaphora, } \\
\text { Inconsistencies, Inferences, Changing Stories and Integrating Knowledge }\end{array}$ \\
\hline Switching & อิอิ & Anaphora, Inconsistencies, Inferences and Integrating Knowledge \\
\hline Connection with knowledge & & $\begin{array}{l}\text { Vignettes in Order, Decoding Instructions, Sentences in Order, Anaphora, } \\
\text { Inferences and Changing Stories }\end{array}$ \\
\hline Semantic updating in WM & 5 & $\begin{array}{l}\text { Sentences in Order, Anaphora, Inconsistencies, Inferences, Changing Sto- } \\
\text { ries and Integrating Knowledge }\end{array}$ \\
\hline Inhibition & & $\begin{array}{l}\text { Vignettes in Order, Decoding Instructions, Sentences in Order, Anaphora, } \\
\text { Inconsistencies, Changing Stories and Integrating Knowledge }\end{array}$ \\
\hline
\end{tabular}

Source: Own work. 
Finally, the inhibition of irrelevant information concerns tasks in which children need to inhibit or override the tendency to produce a more dominant or automatic response. In order to make each executive function concrete and easy to understand, different symbols were illustrated graphically and presented to students throughout the training program (see Table 1). Concretely, Focusing was illustrated as a magnifying glass, Switching as two eyes looking in different directions, Connection with long-term knowledge as a fishing rod with a globe, Updating of mental representations as a fishing rod with a book, and finally, Inhibition of irrelevant information was illustrated with a stop-sign. The tasks used to tap into each executive function are presented in Table 1.

We used an intervention design with pre-training and post-training measures in an experimental and control group. The training program consisted of ten sessions over a three-week period (50 min/ day). Two researchers carried out the training in the classroom during the ordinary school period. They used student's workbooks to fill out the solutions of the tasks, plus Power Point presentations. Participants were assessed on reading comprehension before and after training. To measure reading comprehension, we used a Spanish version of the Diagnostic Assessment of Reading Comprehension (DARC; August, Francis, Hsu \& Snow, 2006; Francis et al., 2006), called EDICOLE (see García Madruga et al., 2010). The task requires children to silently read three short texts and answer 44 related comprehension questions.

Presented in narrative-style, the texts consist of four small paragraphs that describe transitive relations among a set of real and artificial entities. For instance, "Maria likes to eat fruit. Most of all,

FIGURE 1

Some exemples of the different tasks used in the training of working memory executive functions. Numbers correspond to the tasks described in Table 1.

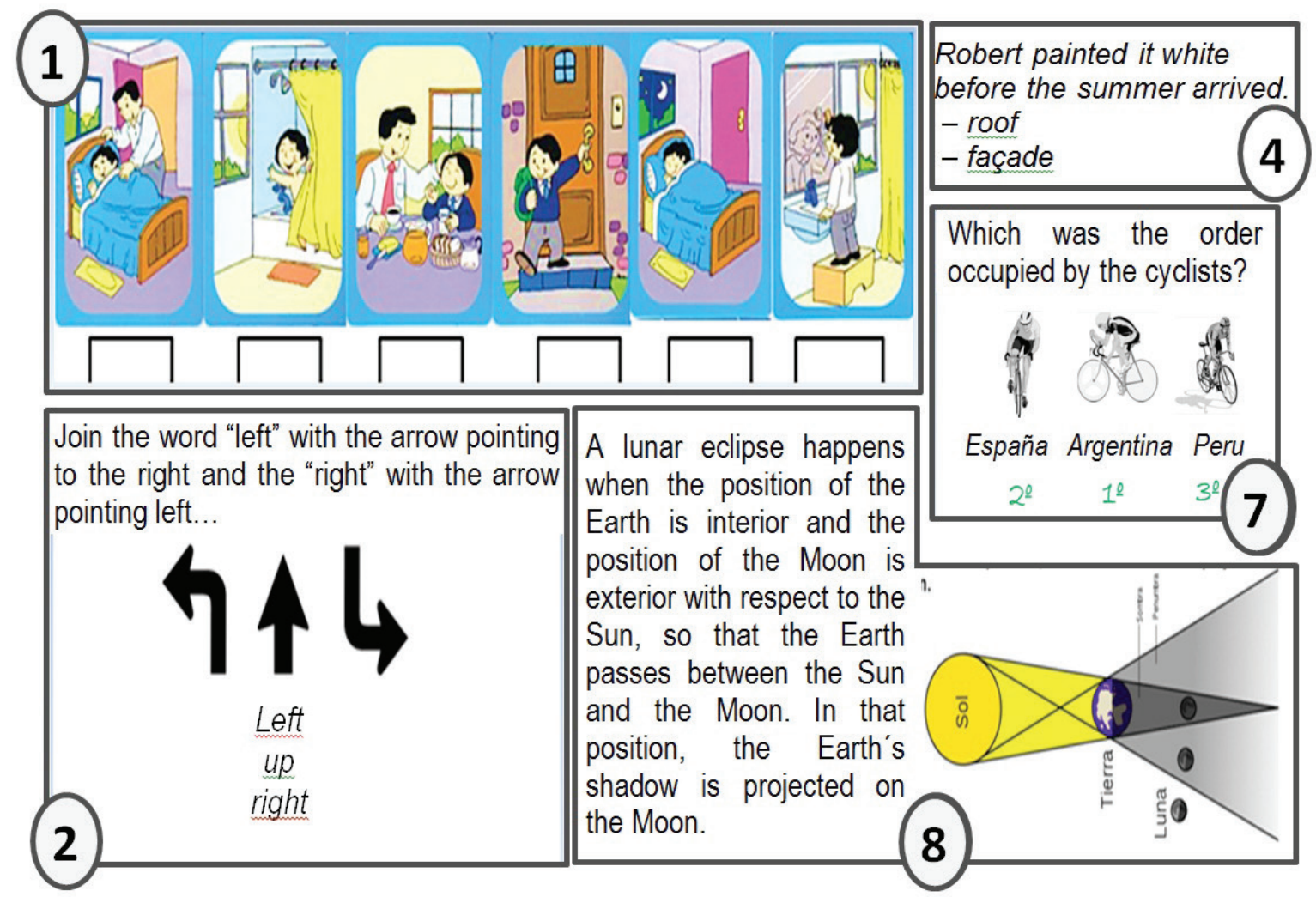

Source: Own work. 
she likes to eat nuras. A nura is like an orange. But a nura is bigger than an orange". Combining the information in the text with world knowledge should, in principle, allow for the construction of a five-entity-long linear ordering along a dimension that is likely to be familiar to all children. Three of the entities are unknown to all readers (artificial terms) and they are presented as nonsense words, whereas two of the entities referred to are likely to be known by all children (real terms) and differ strikingly on the critical dimension. After each text, readers are asked a series of sixteen "yes-no-I don't know" questions.

The comprehension questions are designed to assess readers' performance on four central comprehension processes: (a) knowledge access, i.e., accessing relevant prior knowledge from long-term memory (e.g., "An orange has a peel"); (b) text memory, i.e., recalling from memory new information presented in the text (e.g., "Maria likes to eat fruit"); (c) inferences, i.e., making novel inferences based on information provided in the text but without prior knowledge (e.g., "A nura is smaller than an orange"); and (d) integration, i.e., integrating accessed prior knowledge with new text information (e.g., "You peel a nura to eat it"). Participants are encouraged to read the text carefully at their own pace and to answer the comprehension questions without having the text in front of them. The task is preceded by a practice text and some comprehension questions across each category. The scores are based on the number of correct answers in the four categories of questions related to the basic processes underlying reading comprehension.
Children performed different tasks each day, selected from a bank of eight tasks: Vignettes in Order, Sentences in Order, Decoding Instructions, Anaphora, Inconsistencies, Inferences, Changing Stories and Integrating Knowledge. In the vignettes in order and sentences in order tasks children were asked to organize either a series of vignettes or a series of sentences into the logical order, in order to create a coherent story. The decoding instruction task requested them to interpret and perform complex written instructions involving the integration of a sequence of actions. To do that, they had to read the instructions presented on a screen and then either write down or draw the information received in their workbooks. In the Anaphora task children have to solve either syntactic and semantic anaphora problems, and store and remember the word solution in a growing series of inferential problems.

They had to read to themselves the anaphora problems presented on a screen, and then recall the word solution of each anaphora problem and write them down in the correct order. The Inconsistencies task requested students to act as a detective whose job consisted of looking for mistakes in the texts. They read texts containing an internal inconsistency (i.e. inconsistency between two ideas expressed within the text) and an external inconsistency (i.e. information that conflicted with their prior knowledge). The task of the student consisted of detecting one inconsistency of both types within each text. When performing the Inferences task, students had to read different short texts presented on a screen and answer embedded questions that

TABLE 2

The distribution of the eight tasks through the sessions in the intervention program.

\begin{tabular}{lll}
\hline \multicolumn{1}{c}{ TASKS } & \multicolumn{1}{c}{ Variable of difficulty } & \multicolumn{1}{c}{ Sessions } \\
\hline Arranging vignettes in logical order. & $n$ vignettes & 1,2 \\
Interpreting and performing written instructions. & $n$ instructions & 2,3 \\
Arranging textual sentences in logical order. & $n$ sentences & 3,4 \\
Solving anaphora. & $n$ words to be remember & 4,5 \\
Detecting textual inconsistencies. & Distance \& salience & $5,6,7$ \\
Making textual and prior knowledge inferences. & Distance \& causality & 6,7 \\
Following changing stories. & $n$ units to be followed & 8,9 \\
Integrating information from different formats. & $n$ units to be integrated & 8,9 \\
\hline
\end{tabular}

Source: Own work. 
either require the integration among individual sentences in the text (i.e. text-based inferences) or demand the integration of general knowledge with information in the text (i.e. elaborative inferences).

In the changing stories task, children read different texts including a stream of information in which relevant facts are constantly changing. They were asked to actively keep track of the information as they read it because, in several points of the story, they were requested to determine the state of different parts of the story at that time (e.g. the order of the horses in a race, the state of the scoreboard during a football match). Finally, the training program included the Integrating knowledge task. This activity required children to focus and switch their attention to different units of information presented on a screen in different formats (i.e. text, video, pictures) in order to be able to answer several questions that required the integration of multiple sources of information. To keep children motivated throughout the program, at the end of each session they performed the Motoric instructions. To do this, they had to read some instructions presented on a screen and then execute with their body some funny postures and movements. Additionally, at the end of each week of training, children were awarded with a diploma and a small gift.

Students performed the eight different tasks that were designed to boost the four executive functions. All tasks consisted of several items that were presented in order of increasing difficulty. Each task was trained by means of four modes of instruction: explicit instruction in the executive functions related to the tasks, modeling examples, guided practice and independent practice.

Our data show that students performed significantly better on the reading comprehension measures after training. Moreover, trained participants also improved their scores in fluid intelligence and on executive tasks (García-Madruga et al., 2012). These results clearly confirm that reading comprehension is a complex cognitive process in which the executive processes are highly implicated. Therefore, it is possible to develop some intervention programs that improve reading comprehension by boosting the central executive functions involved (focusing, switching, connecting with long-term information and updating, and inhibition). These findings provide support to this training perspective regarding reading comprehension (Chein \& Morrison, 2010; Klingberg, Forssberg, \& Westerberg, 2002; Klingberg, 2010).

Nevertheless, we would like to emphasize that, as suggested by recent criticism (Melby-Lervåg \& Hulme, 2012; Morrison \& Chein, 2011; Shipstead, Hicks, \& Engle, 2012; Shipstead, Redick, \& Engle, 2012), this work is clearly open to further study: The results found have to be confirmed with training experiments that use more complete designs. Likewise, it is also necessary to investigate the maintenance and durability of the effects found.

\section{Conclusions}

The research on reading comprehension intervention described in this work can be integrated in whole-class, small groups, or individual instruction. Interventions in reading comprehension can be implemented in school by developing specific comprehension strategies such as teaching the main idea and summarization skills. However, some recent studies have begun to develop a different approach that focuses on working memory's executive processes (e.g. focusing, switching, connecting and updating mental representations, and the inhibition of irrelevant information).

The role of the working memory system in reading comprehension has been highlighted from classical text comprehension models. Reading comprehension is often a complex process that is achieved within working memory and requires a great deal of cognitive resources, including storage and processing efficacy. Reading comprehension is hence a task in which the executive processes are highly implicated. The specific training program focused on working memory's executive functions is an example of what researchers might do to grasp how, when and why the reading comprehension process can be improved in the school setting. In this paper, we have presented a training program based on working memory's executive 
processes of repetition, feedback and the gradual adjustement of difficulty, and one that shows the effectiveness of the "adaptative training", as some recent studies have suggested (Holmes et al., 2009; Klingberg, 2010).

We have not explicitly trained any particular strategy, but the training explicitly demanded students to actively and consciously engage throughout the entire training process, from the first to the final session. In fact, the main focus was not to train reading comprehension itself, but to train WM's executive processes, that is, the conscious control of cognitive processes involved in reading comprehension. Obviously, our proposal of using repetitive practice ultimately addressed at the outcome of achieving some kind of automated behavior, but in a way that is always monitored and under the control of executive processes.

Therefore, it can be seen that any intervention attempting to improve reading comprehension seems to progress from the intervention of specific cognitive strategies towards the intervention of working memory's executive processes.

\section{References}

August, D., Francis, D.J., Hsu, H.A., \& Snow, C.E. (2006). Assessing reading comprehension in bilinguals. The Elementary School Journal, 107(2), 221-238.

Baddeley, A.D., \& Hitch, G. (1974). Working Memory. In G.A. Bower (Ed.). The Psychology of Learning and Motivation, vol.8, (pp. 47-90). New York: Academic Press.

Baker, L., \& Beal, L.C. (2009). Metacognitive Processes and Reading Comprehension. In. S.E. Israel \& G.G. Duffy (Eds.). Handbook of Research on Reading Comprehension (pp. 373-388). New York: Routledge.

Baker, L., \& Brown, A.L. (1984). Metacognitive skills and Reading. In P.D. Pearson (Ed.) Handbook of Reading research (pp. 353-394). New York: Longman.

Baumann, J.F. (1984). The effectiveness of a direct instruction paradigm for teaching main idea comprehension. Reading Research Quarterly, 20, 93-115.
Baumann, J.F. (1986). Teaching main idea comprehension. Newark, DE: International Reading Association.

Block, C.C., \& Pressley, M. (Eds.) (2002). Comprehension Instruction. Research-Based Best Practices. New York: The Guilford Press.

Block, C.C., Gambrell, L.B., \& Pressley, M. (Eds.) (2002). Improving Comprehension Instruction. Rethinking Research, Theory, and Classroom Practice. San Francisco: Jossey-Bass.

Brown, A.L. (1978). Knowing when, where, and how to remember: A problem of metacognition. In R. Glaser (Ed.), Advances in instructional psychology (pp. 157-165). Hillsdale, NJ: Erlbaum.

Brown, A.L., \& Day, J.D. (1983). Macrorules for summarizing texts: The development of expertise. Journal of Verbal Learning and Verbal Behavior, 22, 1-14.

Caccamise, D., Franzke, M., Echkoff, A., Kintsch, E., \& Kintsch, W. (2007). Guided Practice in Technology-Based Summary Writing. In D.S. McNamara (Ed.). Reading Comprehension Strategies: Theories, interventions and Technologies (pp. 375-396). New York: Lawrence Erlbaum Associates.

Cain, K. (2006). Children's reading comprehension: The role of working memory in normal and impaired development. In S.J. Pickering (Ed.). Working Memory and Education (pp. 61-91). San Diego, CA: Academic Press.

Cain, K., \& Oakhill, J. (2007). Reading comprehension difficulties: Correlates, causes, and consequences. In K. Cain \& J. Oakhill (Eds.). Children's comprehension problems in oral and written language: $\mathrm{A}$ cognitive perspective (pp. 41-75). New York: Guilford Press.

Cain, K., Oakhill, J., Barnes, M.A., \& Bryant, P.E. (2001). Comprehension skill, inference making and their relation to knowledge. Memory and Cognition, 29, 850-859.

Cain, K., Oakhill, J.V., \& Lemmon, K. (2004). Individual differences in the inference of word meanings from context: The influence of reading comprehension, vocabulary knowledge, and memory capacity. Journal of Educational Psychology, 96(4), 671-681.

Carretti, B., Borella, E., Cornoldi, C., \& De Beni, R. (2009). Role of working memory in explaining the performance of individuals with specific compre- 
hension difficulties: A meta-analysis. Learning and Individual Differences, 19, 246-251.

Carretti, B., Cornoldi, C., De Beni, R., \& Romanó, M. (2005). Updating in working memory: A comparison of poor and good comprehenders. Journal of Experimental Child Psychology, 91, 45-66.

Chein, J.M., \& Morrison, A.B. (2010). Expanding the mind's worksplace: Training and transfer effects with a complex working memory span task. Psychonomic Bulletin E Review, 17(2), 193-199.

Daneman, M., \& Carpenter, P.A. (1980). Individual differences in working memory and Reading. Journal of Verbal Learning and Verbal Behavior, 19, 450-466.

Daneman, M., \& Merikle, P. M. (1996). Working memory and comprehension: A meta-analysis. Psychonomic Bulletin and Review, 3, 422-433.

Elosúa, M.R., García Madruga, J.A, Gómez-Veiga, I., López-Escribano, C., Pérez, E., \& Orjales, I. (2012). Habilidades lectoras y rendimiento academic en 3 음 y $6^{0}$ de primaria: aspectos evolutivos y educativos. Estudios de Psicología 33(2), 207-218.

Elosúa, M.R., García-Madruga, J.A., Gutiérrez, F., Luque, J.L., \& Gárate, M. (2002). Effects of an Intervention in Active Strategies for text comprehension and recall. The Spanish Journal of Psychology, 5(2), 90-101.

Ericsson, K.A., \& Kintsch, W. (1995). Long-term working memory. Psychological Review, 102, 211-245.

Flavell, J.H. (1976). Metacognitive aspects of problem solving. In L.B. Resnick (Ed.), The nature of intelligence (pp. 231-235). Hillsdale, NJ: Erlbaum.

Francis, D.J., Snow, C.E., August, D., Carlson, C.D., Miller, J., \& Iglesias, A. (2006). Measures of reading comprehension: A latent variable analysis of the diagnostic assessment of reading comprehension. Scientific Studies of Reading, 10(3), 301-322.

García-Madruga, J.A., Elosúa, M.R., Gil, L., Gómez-Veiga, I., Vila, J.O., Orjales, I., Rodríguez, R., Melero, M.A., \& Duque, G. (2013). Intervention on the Central Executive of Working Memory to improve Reading comprehension in Primary school children. Reading Research Quarterly, 48(2), 155-174.

García-Madruga, J.A., Martín Cordero, J. I., Luque, J. L., \& Santamaría, C. (1992) Teaching active text processing strategies. In B. Van Hout-Wolters \& W. Schnotz (Eds.), Text comprehension from differ- ent perspectives (pp.183-200). Amsterdam: SwetsZeitlinger BV.

García-Madruga, J.A., Martín Cordero, J.I., Luque, J.L. \& Santamaría, C. (1995). Comprensión y adquisición de conocimientos a partir de textos. Madrid: Siglo XXI. [Comprehension and knowledge's acquisition from text].

García Madruga, J.A., Pérez, E., Gómez-Veiga, I., Orjales, I., Gil, L., Elosúa, M.R. \& López-Escribano, C. (2010). Prueba de comprensión lectora para enseñanza primaria: EDICOLE (evaluación diagnóstica de la comprensión lectora) [Test of reading comprehension for primary school: EDICOLE (diagnostic assesment of reading comprehension)]. Unpublished work.

Gaskins, I.W., \& Pressley, M. (2007). Teaching metacognitive strategies that address executive function processes within a schoolwide curriculum. In L. Meltzer (Ed.). Executive function in education: From Theory to Practice (261-286). New York: Guilford Press.

Gathercole, S.E., \& Baddeley, A.D. (1993). Working Memory and Language. Hillsdale, NJ: Erlbaum.

Gathercole, S.E., Lamont, E., \& Alloway, T.P. (2006). Working memory in the classroom. In S. Pickering (Ed.). Working memory and Education (pp. 219. 240). San Diego: Academic Press.

Holmes, J., Gathercole, S.E., \& Dunning, D.L. (2009). Adaptative training leads to sustained enhancement of poor working memory in children. Developmental Science, 12, 9-15.

Jitendra, A.K., \& Gajria, M. (2011). Main idea and Summarization instruction to improve Reading comprehension. In Rollanda E. O'Connor \& Patricia F. Vadasy (Eds.) Handbook of Reading Interventions (pp. 198- 219). New York: Guilford Press.

Just, M.A., \& Carpenter, P.A. (1992). A capacity theory of comprehension. Psychological Review, 99, 122 149.

Kamil, M.L., Pearson, P.D., Moje, E.B., \& Afflerbach, P.P. (Eds.). (2011). Handbook of Reading Research (Volume IV). New York: Routledge.

Kintsch, W. (1988). The role of knowledge in discourse comprehension: A construction-integration model. Psychological Review, 2, 163-182. 
Kintsch, W. (1998). Comprehension. A paradigm for cognition. Cambridge, MA: Cambridge University Press.

Kintsch, W., \& Van Dijk, T.A. (1978). Towards a model of text comprehension and production. Psychological Review, 85, 363- 394.

Klingberg, T., Forssberg, H., \& Westerberg, H. (2002). Training of working memory in children with ADHD. Journal of Clinical Experimental Neuropsychology, 24, 781-791.

Klingberg, T. (2010). Training and plasticity of working memory. Trends in Cognitive Sciences, 14, 317-324.

Klingner, J.K., Morrison, A. \& Eppolito, A. (2011). Metacognition to improve Reading comprehension. In R. E. O'Connor \& P. F. Vadasy (Eds.) Handbook of Reading Interventions (pp. 220-253). New York: Guilford Press.

López Escribano, C., Elosúa, M.R., Gómez-Veiga, I., \& García Madruga, J.A. (2013). A predictive study of reading comprehension in third-grade Spanish students. Psicothema, 25(2), 199-205.

McNamara, D.S. (Ed.) (2007). Reading Comprehension Strategies. Theories, Interventions and Technologies. New York: Taylor and Francis Group.

Melby-Lervåg, M., \& Hulme, C. (2012). Is Working Memory Training Effective? A Meta-Analytic Review, Developmental Psychology, in press.

Meltzer, L., Pollica, L., \& Barzillai, M. (2007). Executive Function in the Classroom: Embedding Strategy Instruction into daily teaching practices. In L. Meltzer (Ed.). Executive Function in Education: From Theory to Practice (pp. 165-193). New York: Guilford Press.

Meyer, B.J.F. (1975). The organization of prose and its effects on memory. New York: North-Holland Publishing Company.

Meyer, B.J.F. (1984). Text dimensions and cognitive processing. In H. Mandl, N. Stein, \& T. Trabasso (Eds.), Learning and understanding texts. Hillsdale, NJ: Erlbaum.

Morrison, A.B., \& Chein, J.M. (2011). Does working memory training work? The promise and challenges of enhancing cognition by training working memory. Psychonomic Bulletin EF Review, 18, 46-60.

Oakhill, J., \& Cain, K. (2007a). Issues of casuality in children's Reading comprehension. In D.S. McNamara (Ed.). Children's Comprehension Problems in oral and written language. A Cognitive Perspective (pp. 3-40). New York: The Guilford Press.

Oakhill, J., \& Cain, K. (2007b). Introduction to Comprehension development. In K. Kate \& J. Oakhill (Eds.). Reading Comprehension Strategies: Theories, Interventions, and Technologies (pp. 47-71). New York: The Guilford Press.

Rapp, D.N., Van den Broek, P., McMaster, K.L., Kendeou, P., \& Espin, C.A. (2007). Higher-Order Comprehension Processes in struggling readers: A Perspective for research and intervention. Scientific Studies of Reading, 11(4), 289-312.

Rinehart, S.D., Stahl, S.A., \& Erikson, L.G. (1986). Some effects of summarization training on reading and studying. Reading Research Quarterly, 21, 422-438.

Savage, R., Cornish, K., Manly, T., \& Hollis, C. (2006). Cognitive Processes in Children's Reading and Attention: The role of working memory, divided attention, and response inhibition. British Journal of Psychology, 97, 365-385.

Savage, R., Lavers, N., \& Pillay, V. (2007). Working memory and Reading difficulties: What we know and what we don't know about the relationship. Educational Psychology Review, 19, 185-221.

Shipstead, Z., Hicks, K.L., \& Engle, R.W. (2012). Working memory training remains a work in progress. Journal of Applied Research in Memory and Cognition, 1, 217-219.

Shipstead, Z., Redick, T.S., \& Engle, R.W. (2012). Is working memory training effective? Psychological Bulletin, 138(4), 628-654.

St Clair-Thompson, H.L., \& Gathercole, S. (2006). Executive functions and achievements in school: Shifting, updating, inhibition, and working memory. The Quarterly Journal of Experimental Psychology, 59 (4), 745-759.

Stevens, R.J. (1988). Effects of strategy training on the identification of the main idea of expository passages. Journal of Educational Psychology, 80, 21-26.

Sweet, A.P. (2003). A Research Program for improving reading comprehension. A Glimpse of studies whose findings will aid the classroom teacher in the future. In A.P. Sweet \& C. Snow (Eds.). Rethinking reading comprehension (pp. 207-218). New York: The Guilford Press. 
Sweet, A.P., \& Snow, C. (Eds.). (2003). Rethinking reading comprehension. New York: The Guilford Press.

Van den Broek, P., Lynch, J.S., Naslund, J., Ievers-Landis, C.E., \& Verduin, K. (2003). The development of comprehension of main ideas in narratives: Evidence from the selection of titles. Journal of Educational Psychology, 95, 707-718.

Van Dijk, T.A., \& Kintsch, W. (1983). Strategies of discourse comprehension. New York: Academic Press.

Williams, J.P. (1988). Identifying main ideas: A basic aspect of Reading comprehension. Topics in Language Disorders, 8(3), 1-13.
Williams, J.P. (2004). Teaching text structure to improve reading comprehension. In H.L. Swanson, K.R. Harris, \& S. Graham (Eds.). Handbook of learning disabilities (pp. 293-305). New York: Guilford Press.

Williams, J.P. \& Pao, L.S. (2011). Teaching narrative and expository text structure to improve comprehension. In R. E. O'Connor \& P. F. Vadasy (Eds.) Handbook of Reading Interventions (pp. 254- 278). New York: Guilford Press.

Winograd, P.N. (1984). Strategic difficulties in summarizing texts. Reading Research Quarterly, 19, 404-425. 